\title{
Efektivitas Penggunaan Video Pembelajaran berbasis GeoGebra terhadap Kemampuan Taruna/i dalam Memahami Aplikasi Matematika Maritim
}

\author{
Luthfiana Tarida \\ Akademi Maritim Nusantara, Cilacap \\ luthfianatarida@amn.ac.id
}

Diterima 30 Januari 2021, direvisi 08 Februari 2021, diterbitkan 08 Maret 2021

\begin{abstract}
Abstrak
Perguruan tinggi, dosen dan mahasiswa/i/taruna/i harus dapat beradaptasi dan berinovasi terhadap perubahan paradigma pembelajaran akibat dampak Covid-19. Perkuliahan online saat ini membutuhkan media pendukung agar esensi kontruksi pengetahuan tetap dapat dicapai. Video pembelajaran diduga memiliki efektivitas terhadap konstruksi pengetahuan. Jadi penelitian ini bertujuan untuk menganalisis efektivitas penggunaan video pembelajaran berbasis GeoGebra terhadap kemampuan taruna/i dalam memahami aplikasi matematika maritim. Video pembelajaran tersebut memuat materi matematika standar IMO Model Course 7.03. Materi matematika dikaitkan dengan bidang maritim dan divisualisasi menggunakan software GeoGebra. Jenis penelitian ini merupakan penelitian kuantitatif dengan desain Pre-Experimental Design, dan model desain One Group Pretest-Postest Design. Sampel penelitian berjumlah 33 taruna/i angkatan 2020 Prodi Nautika AMN. Pengumpulan data dilakukan dengan tes (pre-test post-test), wawancara dan studi literatur. Data pre-test dan post-test tidak berdistribusi normal sehingga diolah menggunakan Uji Wilcoxon berbantuan software SPSS. Hasil penelitian menunjukkan penggunaan video pembelajaran berbasis GeoGebra lebih efektif secara signifikan terhadap kemampuan taruna/i memahami aplikasi matematika maritim. Video pembelajaran dapat meningkatkan motivasi taruna/i di AMN untuk belajar matematika. Hal tersebut dikarenakan materi aplikasi matematika maritim yang sebagian berupa geometri, sangat terbantu dengan visualisasi animasi 3D dari GeoGebra.
\end{abstract}

Kata kunci : Video Pembelajaran, GeoGebra, Kemampuan Memahami, Aplikasi Matematika Maritim

\begin{abstract}
Universities, lecturers and students/ cadets must be able to adapt and innovate to changes in the learning paradigm due to the impact of Covid-19. Online lectures currently require supporting media so that the essence of knowledge construction can still be achieved. Learning videos are thought to have effectiveness on knowledge construction. This research aims to analyze the effectiveness of using GeoGebra-based instructional videos on the ability of cadets to understand maritime mathematics applications. The learning video contains standard mathematics material of IMO Model Course 7.03. Mathematical materials are related to the maritime field and visualized using GeoGebra software. This type of research is a quantitative study with a Pre-Experimental Design design, and a One Group Pretest-Postest Design model. The research sample consisted of 33 cadets of the 2020 batch of Nautics AMN. The data was collected by means of tests (pre-test post-test), interviews and literature studies. The pre-test and post-test data were not normally distributed so they were processed using the Wilcoxon test assisted by SPSS software. The results showed that the use of GeoGebra-based learning videos was significantly more effective in the ability of cadets to understand maritime mathematics applications. Video lessons can increase the motivation of cadets at AMN to learn mathematics. This is because the application material for maritime mathematics, which is partly in the form of geometry, is greatly helped by the 3D animation visualization from GeoGebra.
\end{abstract}

Keywords $\quad$ : Learning Videos, GeoGebra, Understanding Ability, Maritime Mathematics Application. 


\section{Pendahuluan}

Dunia sedang menghadapi dampak virus Covid-19 yang mewabah sejak tahun 2019. Virus tersebut memiliki tingkat penularan yang cukup tinggi apabila orang yang membawa virus saling berdekatan dengan yang lain. Oleh karena itu, seluruh kegiatan, termasuk kegiatan pembelajaran difokuskan tetap menjaga jarak aman. Menteri pendidikan mengeluarkan Surat Edaran Nomor 3 Tahun 2020 tentang Pencegahan Covid-19 Pada Satuan Pendidikan yang menyatakan bahwa meliburkan sekolah dan perguruan tinggi. [1]. Kebijakan Pemerintah merupakan wujud dukungan dalam menekan angka penularan Covid-19. Hal ini didukung oleh Pemerintah Jawa Tengah. Gubernur Jawa Tengah memutuskan seluruh sekolah diliburkan dan kegiatan pembelajaran dilakukan secara online (Surat Edaran nomor 420/0005956 tentang pencegahan penyebaran Covid-19 [1]. Akademi Maritim Nusantara (AMN) yang terletak di Jawa Tengah turut menjadi salah satu Perguruan Tinggi yang menerapkan perkualiahan online. Perkuliahan online di Perguruan Tinggi secara masiv dan total merupakan tantangan bagi dosen dan taruna/i di AMN. Perguruan tinggi, dosen dan taruna/i harus beradaptasi dan berinovasi terhadap perubahan paradigma pembelajaran. Dengan demikian kendala dan hambatan dapat diminimalisir tanpa mengurangi esensi kontruksi pengetahuan.

Baharudin menyatakan penggunaan media pembelajaran yang tepat dapat menjadi perantara bagi siswa untuk memahami materi dan meningkatkan kualitas pembelajaran [2]. Perkuliahan online memerlukan media pembelajaran yang interaktif agar tujuan pembelajaran dapat dicapai. Perkuliahan online bukan sebatas proses transfer materi melalui media digital. Taruna/i akan merasa kesulitan jika pembelajaran sebatas proses mendownload materi tulis. Hal tersebut diperkuat dengan hasil survei kepada taruna/i di AMN. Taruna/i menyatakan bahwa materi Matematika Terapan sulit dipahami jika pembelajaran hanya berupa pengiriman materi melalui media digital.

Perkuliahan online di AMN sudah menggunakan Google Classroom dan aplikasi Meeting online seperti Zoom dan Google Meet. Berdasarkan wawancara dengan mahasiswa pada penelitian terdahulu, diketahui bahwa kendala dalam menggunakan aplikasi Zoom yaitu situasi dan kondisi keadaan lingkungan rumah atau jaringan (sinyal) maka dapat menghambat mahasiswa yang koneksi internetnya lamban [1]. Hal ini juga dialami oleh beberapa taruna/i di AMN. Penelitian sebelumnya menyatakan bahwa pemanfaatan Google Classroom yang dilengkapi dengan video pembalajaran dapat menjadi solusi pembelajaran online di Era Pandemi Covid-19[3]. Video pembelajaran merupakan salah satu media yang lebih fleksibel. Taruna/i tidak harus mendownload video pembelajaraan pada jadwal tertentu. Video pembelajaran didownload kapanpun dimanapun. Jadi taruna/i dapat mencari atau menunggu waktu saat koneksi internet baik untuk mendownloadnya. Berdasarkan survei yang dilakukan pada Program Studi (Prodi) Nautika AMN, diperoleh hasil bahwa 52,2\% taruna/i setuju, belajar melalui video dapat membantu memahami materi dengan baik. Hal tersebut didukung oleh Daryanto yang menyatakan bahwa video merupakan suatu medium yang sangat efektif dalam membantu proses pembelajaran, baik untuk pembelajaran massal, individual, ataupun berkelompok [4]. Taruna/i berpendapat bahwa video pembelajaran memudahkan belajar secara mandiri. Hal ini dimungkinkan karena video dapat diulang-ulang oleh taruna/i berdasarkan kemampuannya.

Video pembelajaran diharapkan dapat menjadi media pelengkap yang efektif dalam meningkatkan prestasi belajar taruna/i memahami materi. Berdasarkan survei sebelumnya taruna/i berpendapat lebih bersemangat saat belajar menggunakan video pembelajaran. Hal ini dapat menjadi dugaan meningkatkatnya kemampuan dan prestasi belajar taruna/i, karena termotivasi untuk belajar. Jika taruna/i merasa tidak termotivasi saat mengikuti pembelajaran, maka dapat menyebabkan taruna/i kurang atau tidak memahami materi yang bersifat sukar yang diberikan dosen. Arsyad menyatakan bahwa proses belajar terjadi karena adanya interaksi antara seseorang dengan lingkungannya, interaksi yang terjadi selama proses belajar dipengaruhi oleh lingkungannya [4]. Video pembelajaran dapat memberikan interaksi sehingga terjadi proses belajar yang maksimal.

Penggunaan video pembelajaran cocok diterapkan pada materi matematika karena membutuhkan realisasi dalam konstruksi konsep matematika yang abstrak. Berdasarkan IMO Model Course 7.03, sebagian besar materi 
matematika Prodi Nautika di AMN, merupakan materi geometri. Materi geometri sangat sesuai dipelajari dengan menggunakan video, seperti yang dikemukakan oleh Gambari, James dan Olumorin bahwa pembelajaran dengan video dapat meningkatkan hasil belajar geometri [2]. Video pembelajaran perlu didukung oleh software lain untuk meminimkan kesulitan taruna/i dalam memahami konsep aplikasi matematika maritim. Contoh pada materi segitiga bola yang berkaitan dengan penerapan kemaritiman bidang ilmu pelayaran datar. Pada materi segitiga bola, taruna/i akan kesulitan jika materi hanya diberikan melalui media dua dimensi. Hal ini karena, segitiga bola merupakan materi geometri ruang dimensi tiga. Oleh karena itu, software GeoGebra dipilih sebagai pendukung video pembelajaran. Taruna/i diharapkan dapat lebih memahami konsep dengan melihat animasi 3D segitiga bola yang dibuat melalui GeoGebra. Alviah dan Rudhito menyebutkan bahwa Geogebra merupakan suatu software yang memiliki fasilitas animasi dan gerak yang dapat memberikan visualisasi yang lebih jelas bagi peserta didik [2].

Penggunaan video pembelajaran dalam memfasilitasi kemampuan taruna/i memahami konsep matematika diperkuat dari penelitian terdahulu. Penelitian di SMK menunjukkan bahwa peningkatan kemampuan pemahaman konsep matematis siswa yang menggunakan video pembelajaran berbasis Geogebra lebih baik dibandingkan siswa yang belajar dengan pembelajaran konvensional. Video pembelajaran berbasis Geogebra efektif dan berpengaruh positif terhadap peningkatan kemampuan pemahaman konsep matematis siswa. Video pembelajaran berbasis Geogebra ini dapat dijadikan sebagai salah satu media pembelajaran untuk meningkatkan kemampuan pemahaman konsep matematis siswa[2]. Oleh karena itu, penelitian ini bertujuan untuk menganalisis efektivitas penggunaan video pembelajaran berbasis GeoGebra terhadap kemampuan taruna/i dalam memahami aplikasi matematika maritim.

\section{Materi dan Metode}

Video merupakan teknologi untuk menangkap, merekam, memproses, mentransmisikan dan menata ulang gambar bergerak [5]. Majid menyatakan, video pembelajaran merupakan media pembelajaran yang komunikatif dan dapat ditayangkan ulang sesuai kebutuhan, menampilkan sesuatu dengan detail dan kompleks, dapat dipercepat, diperlambat, bahkan diperbesar dan membandingkan antara dua atau lebih adegan secara bersamaan [2].

GeoGebra merupakan kepanjangan dari Geometri dan Algebra/aljabar. GeoGebra diciptakan sebagai alat bantu pembelajaran geometri sekaligus aljabar. Nur menyatakan, Geogebra dapat dimanfaatkan sebagai alat bantu visualisasi yang efektif dan efisien. Hohenwarter dan Funchs (Mahmudi) mengungkapkan pemanfaatan GeoGebra pada pembelajaran matematika, sebagai media visualisasi, demonstrasi, alat bantu konstruksi dan proses penemuan konsep-konsep geometri [2]. Software GeoGebra dapat digunakan dengan bebas dan dapat diunduh secara gratis pada laman www.geogebra.com.

Aplikasi matematika maritim merupakan penerapan materi matematika pada bidang maritim, khususnya nautika. Materi matematika maritim yang harus dipahami taruna/i Prodi Nautika berdasarkan IMO Model Course 7.03, yaitu: (1) aljabar; (2) grafik; (3) proporsi, variasi \& interpolasi; (4) geometri; (5) trigonometri; (6) pengukuran bangun datar \& bangun ruang; (7) segitiga bola; (8) vektor; (9) lingkaran, elips, hiperbola; dan (10). Sebagai contoh, materi interpolasi linear dapat dikaitkan dengan perhitungan daftar VII Ilmu Pelayaran.

Video pembelajaran yang digunakan pada penelitian ini memuat materi matematika berdasarkan IMO Model Course 7.03. Materi matematika tersebut dikaitkan dengan bidang maritim dan divisualisasi menggunakan software GeoGebra.

Jenis penelitian ini merupakan penelitian kuantitatif dengan desain Pre-Experimental Design, dan model desain One Group PretestPostest Design. Model desain tersebut dapat digambarkan seperti berikut [6]:

Keterangan:

$$
\mathrm{O}_{1} \mathrm{XO}_{2}
$$

$O_{1}$ : Pre-test kemampuan mahasiswa dalam memahami aplikasi matematika maritim

$X$ : Perlakuan dengan menggunakan video pembelajaran berbasis GeoGebra

$\mathrm{O}_{2}$ : Post-test kemampuan mahasiswa dalam memahami aplikasi matematika maritim

Penelitian ini bertujuan menganalisis efektivitas variabel independen terhadap variabel 
dependen. Variabel dependen pada penelitian ini berupa kemampuan taruna/i dalam memahami aplikasi matematika maritim. Variabel independen pada penelitian ini berupa penggunaan video pembelajaran berbasis GeoGebra. Sampel penelitian berjumlah 33 taruna/i angkatan 2020, Prodi Nautika AMN.

Metode pengumpulan data dilakukan dengan wawancara, tes dan studi literatur. Wawancara dilakukan untuk mengetahui pendapat taruna/i mengenai pembelajaran jarak jauh. Tes dilakukan untuk memperoleh data kemampuan taruna/i dalam memahami aplikasi matematika maritim. Tes terbagi menjadi dua, yaitu pre-test dan post-test. Pre-test diberikan kepada taruna/i sebelum adanya perlakuan penggunaan video pembelajaran berbasis GeoGebra. Post-test diberikan kepada taruna/i setelah adanya perlakuan penggunaan video pembelajaran berbasis GeoGebra. Studi literatur digunakan untuk meperoleh literasi kredibel yang mendukung penelitian.

Data pre-test dan post-test diolah menggunakan uji $\mathrm{T}$ (Paired Sample T-Test) menggunakan software SPSS. Uji Normalitas dilakukan dengan teknik Shapiro Wilk. Uji normalitas dilakukan sebelum melakukan Paired Sample T-Test. Jika data berdistribusi tidak normal, dilakukan uji pengganti Paired Sample T-Test, yaitu Uji Wilcoxon. Taraf signifikansi yang digunakan dalam penelitian ini yaitu $\alpha=0,05$.

Rumusan hipotesis dari uji statistik dijabarkan sebagai berikut:

$H_{0}$ : Penggunaan video pembelajaran berbasis GeoGebra tidak efektif secara signifikan terhadap kemampuan taruna/i memahami aplikasi matematika maritim

$H_{匹}$ : Penggunaan video pembelajaran berbasis GeoGebra efektif secara signifikan terhadap kemampuan taruna/i memahami aplikasi matematika maritim.

\section{Hasil dan Pembahasan}

\section{Uji Normalitas}

Output SPSS Uji Normalitas data pre-test dan post-test dirangkum pada Tabel 1 berikut.

Tabel 1. Rangkuman Uji Normalitas

\begin{tabular}{cc}
\hline Data & Sig. Shapiro Wilk \\
\hline Pre-test & 0,00 \\
Post-test & 0,02 \\
\hline
\end{tabular}

Pada Tabel 1, diketahui data pre-test memiliki nilai Sig. $=0,00<0,05$ sehingga disimpulkan data pre-test kemampuan taruna/i memahami aplikasi matematika maritim tidak berdistribusi normal. Data post-test memiliki nilai Sig. $=0,02<0,05$ sehingga disimpulkan data post-test kemampuan taruna/i memahami aplikasi matematika maritim, tidak berdistribusi normal.

\section{Uji Wilcoxon}

Data pre-test dan post-test tidak berdistribusi normal sehingga dilakukan uji statistitik nonparametrik yaitu Uji Wilcoxon. Output Rank dari Uji Wilcoxon menggunakan bantuan SPSS dirangkum pada Tabel 2 berikut.

Tabel 2. Rangkuman Rank dari Uji Wilcoxon

\begin{tabular}{cccc}
\hline $\begin{array}{c}\text { Pre-test } \\
\text { Post-test }\end{array}$ & Jumlah & $\begin{array}{c}\text { Mean } \\
\text { Rank }\end{array}$ & $\begin{array}{c}\text { Sum of } \\
\text { Ranks }\end{array}$ \\
\hline Negative Ranks & 0 & 0 & 0 \\
Positif Ranks & 31 & 16 & 496 \\
Ties & 2 & & \\
Total & 33 & & \\
\hline
\end{tabular}

Berdasarkan Tabel 2, diketahui jumlah negative rank adalah 0 . Jadi tidak ada selisih negatif antara data pre-test dan post-test. Tidak ada nilai pre-test yang lebih tinggi dari nilai post-test. Secara deskriptif dapat disimpulkan terjadi peningkatan kemampuan taruna/i dalam memahami aplikasi matematika maritim, setelah dilakukan perkuliahan menggunakan video pembelajaran berbasis GeoGebra. Jumlah positive rank adalah 31 dari 33 taruna/i. Terdapat 31 taruna/i yang mengalami peningkatan kemampuan taruna/i memahami aplikasi matematika maritim, setelah dilakukan perkuliahan menggunakan video pembelajaran berbasis GeoGebra. Rata-rata peningkatan tersebut sebesar 16 dan jumlah ranking positif sebesar 496.

Tabel 3 berikut merangkum hasil uji hipotesis Wilcoxon menggunakan SPSS.

Tabel 3. Rangkuman Uji Hipotesis Wilcoxon

\begin{tabular}{cc}
\hline & Pre-test Post-test \\
\hline $\mathrm{Z}$ & $-4,881$ \\
Asymp.Sig. (2-tailed) & 0,00 \\
\hline
\end{tabular}

Berdasarkan Tabel 3, diperoleh nilai Asymp.Sig. (2-tailed) $=0,00<0,05$ sehingga dapat ditarik kesimpulan $H_{0}$ ditolak. Jadi, penggunaan video pembelajaran berbasis GeoGebra efektif secara 
signifikan terhadap kemampuan taruna/i memahami aplikasi matematika maritim.

Menurut Kesumawati, Murizal, Yarman, \& Yerizon, yang menyatakan bahwa salah satu tujuan utama dalam pembelajaran matematika adalah siswa harus memahami konsep[2]. Dengan kata lain, penggunaan video pembelajaran berbasis GeoGebra dapat mewujudkan tujuan utama pembelajaran matematika.

Video sebagai medi pembelajaran diduga dapat meningkatkan motivasi taruna/i dalam belajar sehingga kemampuan dalam memahami konsep matematis juga meningkat. Hamalik dalam Azhar mengemukakan bahwa pemakaian media pembelajaran dalam proses belajar mengajar dapat membangkitkan keinginan dan minat baru, membangkitkan motivasi dan rangsangan belajar [7].

Video merupakan gabungan dari media audio dan visual. Haryoko menyatakan, media audio visual dapat menjadi alternatif sarana optimalisasi proses pembelajaran dan menjadikan pembelajaran lebih efektif, baik dari segi waktu maupun materi yang disampaikan [2]. Video pembelajaran pada penelitian ini dapat menjadi alternatif perkuliahan online di Era Pandemi Covid-19. Perguruan Tinggi dapat menjawab tantangan perkuliahan online saat ini dengan penggunaan video pembelajaran.

Efektivitas penggunaan video pembelajaran diperkuat dengan hasil penelitian terdahulu dari berbagai jenjang pendidikan. Pada tingkat SMP, hasil belajar siswa yang menggunakan video pembelajaran lebih efektif daripada hasil belajar siswa yang menggunakan model pembelajaran konvensional pada materi persamaan garis garis lurus [8].

Pada tingkat SMK, peningkatan hasil belajar dengan menggunakan media pembelajaran video terjadi karena siswa mendapatkan pengalaman baru dalam menerima materi. Peningkatan ratarata dari hasil pre test dan post test menunjukan bahwa peserta didik sampel penelitian mengalami peningkatan sebesar 14.28 dengan rata-rata pre test 70.41 menjadi 84.69 pada ratarata post test [4]. Penggunaan media pembelajaran berupa video animasi dapat mengefektifkan proses pembelajaran Mata Pelajaran Strategi Pemasaran sub materi Maurity Stage dan Decline Stage di SMKN 4 Surabaya. Penggunaan media video animasi dapat meningkatkan hasil belajar siswa, yang diketahui dari perbedaan rerata nilai hasil formatif test pada kelas kontrol dengan kelas eksperimen, dimana kelas eksperimen memiliki rerata lebih tinggi dibandingkan kelas kontrol [9].

Pada tingkat perkuliahan, menunjukkan adanya perbedaan prestasi antara kelas yang menggunakan video pembelajaran dan yang tidak. Hal tersebut ditunjukkan dengan rata-rata 73,25 pada kelas yang menggunakan video pembelajaran dan 68,30 pada kelas yang tidak menggunakannya. Variabel kreativitas mahasiswa juga berpengaruh positif terhadap prestasi belajar [5].

Penelitian sebelumnya menyatakan penggunaan video pembelajaran matematika efektif digunakan dalam proses pembelajaran pada materi segitiga dan segiempat [7]. Materi aplikasi matematika maritim, sebagian besar merupakan materi geometri. Oleh karena itu video pembelajaran dapat meningkatkan kemampuan taruna/i dalam memahami aplikasi matematika maritim.n hasil kesimpulan Anda dalam bagian ini. Singkat saja tetapi jelas. Jangan mengulang terlalu banyak hal-hal pada bagian Hasil dan diskusi, akan tetapi rangkumkan. Bagian ini cukup satu paragraf saja.

\section{Kesimpulan}

Kesimpulan penelitian ini yaitu penggunaan video pembelajaran berbasis GeoGebra lebih efektif secara signifikan terhadap kemampuan taruna/i memahami aplikasi matematika maritim. Video pembelajaran dapat meningkatkan motivasi taruna/i di AMN untuk belajar matematika. Hal tersebut dikarenakan materi aplikasi matematika maritim yang sebagian berupa geometri, sangat terbantu dengan visualisasi animasi 3D dari GeoGebra.

\section{Ucapan terima kasih}

Penulis mengucapkan terima kepada AMN atas dukungannya dalam kegiatan ilmiah ini dan menjadi tempat terselenggaranya penelitian.

\section{Daftar Pustaka}

[1] E. Windhiyana, "Dampak Covid-19 Terhadap Kegiatan Pembelajaran Online Di Perguruan Tinggi Kristen Di Indonesia," Perspekt. Ilmu Pendidik., vol. 34, no. 1, pp. 
1-8, 2020, doi: 10.21009/pip.341.1.

[2] E. Nurdin, A. Ma'aruf, Z. Amir, R. Risnawati, N. Noviarni, and M. P. Azmi, "Pemanfaatan video pembelajaran berbasis Geogebra untuk meningkatkan kemampuan pemahaman konsep matematis siswa SMK," J. Ris. Pendidik. Mat., vol. 6, no. 1, pp. 87-98, 2019, doi: 10.21831/jrpm.v6i1.18421.

[3] L. Tarida, "Pemanfaatan Google Classroom dan Video Pembelajaran berbasis Problem Solving sebagai Solusi Kegiatan Belajar Mengajar di Era Pandemi Covid-19," Saintara J. Ilm. Ilmu-Ilmu Marit., vol. 5, no. 1, pp. 16-20, 2020, [Online]. Available: https://amn.ac.id/ojs/index.php/saintara/artic le/view/88.

[4] R. Fitrianingsih and Musdalifah, "Efektivitas Penggunaan Media Video Pada Pembelajaran Pembuatan Strapless Siswa Kelas XII SMK Negeri 1 Jambu," Fash. Fash. Educ. J., vol. 4, no. 1, pp. 1-6, 2015.

[5] D. Rasiman et al., "Efektivitas Pembelajaran dengan Memanfaatkan Video yang dikemas dalam Bentuk CD Interaktif pada Mata Kuliah Inovasi Pembelajaran Matematika," Aksioma, vol. 3, no. 1, pp. 19, 2012.

[6] Sugiyono. 2012. "Metode Penelitian Pendidikan: Pendekatan Kuantitatif, Kualitatif, dan R\&D," Bandung: Alfabeta.

[7] A. Alicea, "Pengembangan Video Pembelajaran Berbasis Kontekstual Berbantu Prezi Dan Geogebra Pokok Bahasan Segitiga Dan Segiempat Di Smp," Aksioma, vol. 7, no. 2, p. 32, 2017, doi: 10.26877/aks.v7i2.1417.

[8] N. Amrina, "Pengembangan Video Pembelajaran Berbantuan Mind Mapping Dan Geogebra Dengan Pendekatan Rme Pada Materi Persamaan Garis Lurus," Aksioma, vol. 7, no. 2, p. 1, 2017, doi: 10.26877/aks.v7i2.1414.

[9] S. Khomariyah, "Analisis Penggunaan Media Video Animasi terhadap Efektivitas Pembelajaran Materi Product Life Cycle," J. Pendidik. Tata Niaga ( JPTN ), vol. 06, no. 1, pp. 145-150, 2018. 